Digilec 8 (2021), pp. 83-98

Fecha de recepción: 28/06/2021

Fecha de aceptación: 15/09/2021

DOI: https://doi.org/10.17979/digilec.2021.8.0.8581
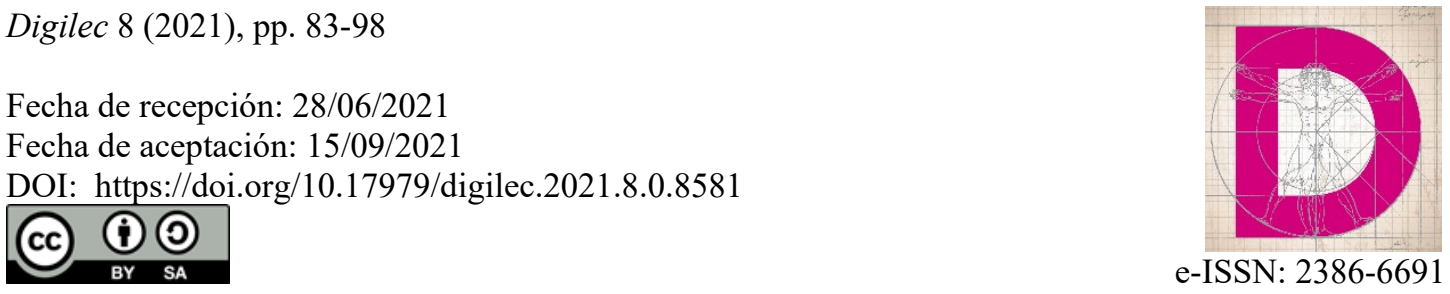

\title{
ANALYSIS OF MR. COLLINS' PROPOSAL: JANE AUSTEN'S REALISM AS A STRATEGY FOR SOCIAL CRITICISM
}

\author{
ANÁLISIS DE LA PROPUESTA MATRIMONIAL DEL SEÑOR \\ COLLINS: EL REALISMO DE JANE AUSTEN COMO ESTRATEGIA \\ PARA LA CRÍTICA SOCIAL
}

\author{
Miguel Ángel JORDÁN ENAMORADO* \\ Universitat de València \\ Orcid: http://orcid.org/0000-0003-4668-1537
}

\begin{abstract}
Jane Austen's novels are a faithful portrait of many of the customs and rules of her time's society. By depicting her sociocultural environment, Austen confers a greater realism to her works and adds coherence to her characters' attitudes. She also employs realism as a strategy to make a subtle social criticism, highlighting the negative consequences of some of her time's laws and rules. In the present article, a sociocultural context is offered about clerics, courtship and marriage proposals, and the legal device of the entailment, which will lead to a better understanding of the subsequent analysis of Pride and Prejudice's chapter 19, in which Mr. Collins' marriage proposal to Elizabeth Bennet is related. Through this analysis, the way in which Austen criticizes the precarious situation of women in her time will be explained, as well as its subsequent consequences on marriage engagements.
\end{abstract}

Key Words: Women's Studies: Literary analysis; Regency novel; cultural studies; novel and history

\section{Resumen}

Las novelas de Jane Austen son un fiel retrato de muchas de las costumbres y reglas de la sociedad de su tiempo. Al reflejar el entorno sociocultural de su época, la autora confiere un mayor realismo a sus obras y aporta coherencia a la actitud de sus personajes. Austen se sirve también del realismo para realizar una sutil crítica social, poniendo de manifiesto las consecuencias negativas de algunas de las disposiciones de su época.

En el presente artículo, se ofrece un análisis del capítulo 19 de Pride and Prejudice, en el que se relata la propuesta de matrimonio de Mr. Collins a Elizabeth Bennet. Por medio de este análisis, precedido de un contexto sociocultural sobre los clérigos, el cortejo, las

* Avda. Blasco Ibáñez, 32. 46010 Valencia. Email: miguel.jordan@uv.es 
propuestas matrimoniales y el entailment, un instrumento legal, se explicará el modo en el que Austen critica la situación de precariedad de las mujeres de su época y las consecuencias de esta situación en los compromisos matrimoniales.

Palabras clave: Estudios de la mujer; análisis literario; novela de la Regencia; estudios culturales; novela e historia 


\section{INTRODUCTION}

More than two hundred years after Jane Austen's death, her novels continue to be reissued and translated into different languages. There are millions of readers who have entered the pages of many of her works. There are various reasons for this success; some readers highlight this author's elegant and ingenious use of irony (Mudrick, 2018), others the personality of her heroines and gentlemen, or her mastery in writing dialogues, the defence of moral values, the romantic stories, etc.

One of the main characteristics of Austen's style is her attention to detail. She compared her way of writing with an artist working with a little bit of ivory, carefully shaping it with a fine brush (Austen, 2011b). That care for detail permeates all the elements of her works: the characters, the dialogues, the lexicon, etc. And we can also find it in the fidelity with which she portrays her sociocultural context.

In her works, Austen conducts a detailed study of the characters, analysing their personality through their acts and speeches (Jordán, 2017). Austen's characters are revealed through their words, both by what they say and by how they say it. She designs each of these characters with her usual attention to detail, and makes them behave according to the sociocultural environment of that moment.

Austen experienced personally the limitation of women in her time and, as a part of society, she knew their disadvantaged situation (Ailwood, 2021, Puspita et al, 2019). For this reason, in her novels, she did not omit these situations and, using irony, she highlighted her period's sex inequalities and the consequences that derived from them (Brownstein, 1988). However, Austen did not carry out this social criticism in a direct and reactionary way. In fact, due to the subtlety of her criticism, it often passes unnoticed to a portion of Austen's readers.

In the present article, we will analyse chapter 19 of Pride and Prejudice, in which Mr. Collins' marriage proposal to Elizabeth Bennet is related, with the purpose of highlighting the social criticism contained in that scene. For this purpose, we will first offer a brief sociohistorical context, which will allow us a better understanding of this chapter's contents.

First, we will present an approach to the situation of clergymen in eighteenthcentury England. Although Pride and Prejudice was published in 1813, the first draft was finished at least fifteen years before. Afterwards, that period's courtship and marriage proposals customs and rules will be summarized. Next, the legal device of the entailment will be explained, which is of great relevance in this novel as it affects decisively the Bennets' economic future. Once this task is finished, we will analyse chapter 19 of Pride and Prejudice by commenting its most relevant paragraphs in light of the mentioned sociohistorical context. Finally, the conclusions drawn from this analysis will be offered. 


\section{HISTORICAL CONTEXT}

\subsection{Clergymen in eighteenth-century England}

In the eighteenth century, virtually all of English society belonged to the Anglican Church. Less than six percent of England and Wales' population disagreed with the established Church (Jacob, 2007). Religious practice was part of the daily life of people of all social classes and, at the same time, it conferred a sense of unity and belonging to the nation, which strengthened the subjects' loyalty to their monarch (Hempton, 1996). According to Jacob (2007), religion was a central part of life for citizens and for the State:

For example, in thanksgivings for victories in war and in local life, in the rhythms of the agricultural and working year, for example, at Rogationtide, and for fairs on local saints days, and, later, for friendly society festivals. The established Church met a broad range of needs, not just for the obviously pious, by providing a framework for child rearing in the Catechism and schools, rites of passage, and days of penitence and prayer, as well as festivals and celebrations. (Jacob, 2007: 8)

The Church and its ministers exercised a unifying role within society, since their work was not limited to liturgical celebrations, but was present in the various facets of social life. Clergymen were a fundamental part of each population, since they helped to promote solidarity among its members both with their work and with their presence.

As Jacob explains in his article, the Church of England's clergymen performed three tasks in society. Firstly, they fulfilled an ecclesiastical mission, not only leading the liturgical celebrations and fostering piety among their parishioners, but also collaborating in their education through the parish schools. Secondly, clergymen played a social role, living with their parishioners, fulfilling their obligations, and performing service tasks to society. And, finally, the clergy acted in the name of the government, since the parish was part of the public administration and it was the main communication channel of the crown and the government.

According to a study conducted by Viviane Barrie-Curien (1992), during the eighteenth century the number of clerics coming from plebeian families decreased, as well as the number of clergymen's sons who decided to be ordained clergymen. However, the number of clergymen from the gentry increased. Although, Barrie-Curien suggests that most of these clerics did not belong to the rural nobility, nor were they minor children of families of ancestry, but their parents were merchants whose wealth had earned them the status of "gentleman" or "esquire".

Once they were ordained, the new clergymen had to achieve a post that would allow them to earn an income. According to Jacob, most returned to their diocese and obtained that first post through their contacts, such as their family, friends, college, etc. So, in the event that a cleric did not have those connections, his situation was much more complicated. For this reason, it was very important for clergymen to have the patronage of some relevant person.

When a post became vacant, the patron or patroness had to choose a candidate and present him to the bishop. After the bishop granted the corresponding permission, the 
incumbent took possession of the parish, which would grant him a post for life, except if he committed a serious moral fault, in which case, the post would be taken away.

The purpose of this patronage was to ensure that the parish clergymen were the appropriate people to fulfil their mission, and that they counted on the recommendation of respectable people who endorsed their good qualities. Although patronage may have been a property right, it also carried obligations and was seen as a trust:

Patrons of livings were trustees - for the well-being of the clergy, the parishioners, and the Church and the good ordering of society. There was a mutuality about the patron-client relationship, in which, although one might be superior and the other inferior, they assisted one another for their mutual interest. Patrons usually had an interest in the well-being of a parish, and might well be benefactors of a parish, and its incumbents (...). In return, clergy gave allegiance, gratitude, and cooperation to their patron. (Jacob, 2007: 70)

The patron watched over the well-being of the parish clergyman and his family, and the clergymen had to thank these attentions, carrying out their tasks with efficiency, showing an exemplary attitude towards their parishioners and attending to them with solicitude and affection. The patrons could impose some conditions on the parish clergymen, such as requiring them to live in the parsonage for a better fulfilment of their mission.

The administration of the parsonage depended entirely on the parish clergyman, who had to maintain it adequately and was subject to the possible inspection visit of the bishop or the archdeacon. The lifestyle of the clergy was quite similar to that of the more prosperous parishioners, and, as a common practice, their patrons would provide them with some comforts:

The parsonage usually comprised a complex of buildings including a house with domestic and agricultural buildings such as a brew house, bake house, wash house, dairy, and 'necessary house' or privy, and usually a barn in arable areas, or in pastoral areas, housing for cattle, pigs, and storage for hay. The average late-seventeenth century parsonage house was probably very like, or perhaps a little bigger than, a yeoman's house. (Jacob, 2007: 150)

In the Anglican Church, clergymen can get married and, during the eighteenth century, more than half of the clergymen were married. Frequently, the wives of these parish clergymen came from the gentry or were the daughters of other clerics. Wives played a very important role in the administration of the parsonage, especially those with small incomes, and carried out some domestic tasks that could include farm work. They could also collaborate with their husbands in some of the parishioners' assistance tasks, and they gave their husbands moral and spiritual support to develop their ministry. In the event that the clergyman had not married or was a widower, a single sister or a niece could carry out these tasks.

Both the wife of a parish clergyman and his family were in a very vulnerable position since, in the case of his death, they lost their home and their income. There were very few options for obtaining any sustenance for these widows, who, in the best of cases, could work in a school. For this reason, since the end of the seventeenth century, various charities were created to provide financial assistance to clergymen's widows in need. 
The clergy were part of the social life of the place where they resided and were related to people of all social levels. Therefore, it was necessary that their situation was consistent with the people in their environment, so that they could deal with them in an equal situation.

The distinction of the clergy ought, in some measure, to correspond with the distinctions of lay society: in order to supply each class of the people with a clergy of their own level and description, with whom they could associate on terms of equality. The higher clergy need wealth to live on equal terms with and influence the rich, and poor clergy should live with and influence the poor. (Clark, 2018, 32)

As representatives of God and of the Church, clergymen enjoyed a distinguished position, which allowed them access to different social circles. Bishops and archdeacons exercised their authority and supervised the conduct of the clerics to ensure that it corresponded to what their parishioners expected of them. An exemplary conduct was demanded, also in their external aspect, and, although there was no objection to their participation in various social events, they had to maintain a dignified attitude and avoid anything that could harm their reputation.

\subsection{Courtship and proposals}

During the seventeenth century, marriage agreements were an extended practice and it was assumed that parents would exercise a decisive influence on their children's choice. Although love was a factor to be considered, social position and economic situation were valued in equal or greater measure. However, in the nineteenth century, courtship became a private matter and affection prevailed over all other factors. The eighteenth century is therefore a period of transition between both situations, love becomes more relevant than in the previous century, but social factors are also taken into account (Smith, 1973).

Declarations of love during the eighteenth century were not exempt from connotations of social status and economic power. "On the contrary, declarations of sentiment were inseparable from assertion of status; love and power were intimately connected" (Eustace, 2001: 518). In order to guarantee the success of a marriage proposal, the suitor not only had to guarantee the firmness of his affection, but also the solidity of his economic and social position.

When courting a lady, a young man not only began to build a loving relationship, but also his path to maturity and autonomy. Marriage implied a change of social status, by which the man passed to reach maturity and to own his home. Similarly, ladies, by accepting a marriage proposal, lost the preeminent situation they enjoyed during the courtship period and replaced it with a state of greater security. However, the rhetoric of love was present throughout this process, concealing the social and economic interest involved in the engagement.

In the event that a man was determined to propose to a lady, he was expected to follow the established protocol. First, he should talk to her father, or her mother, if she was a widow, and state his intentions. The parents would transmit this proposal to the lady or, if the suitor enjoyed their approval, they would allow him to make his proposal 
personally. At times, it would be advisable for the suitor to win favour with other influential members of the family (Kloester, 2010). Although the lady was free to decide, the influence of the family could be decisive both in accepting and in rejecting an offer of marriage.

As has already been said, marriage implied an important change of social status for both parties. Men acquired greater independence and social relevance. When getting married, a young man entered the world of adults with his responsibilities and rights. For women, the passage from courtship to marriage also implied a new social positioning. So that, although they were supposed to be a personal matter, engagements had a high public impact and, consequently, men and women had these social circumstances present during the prior "negotiations".

In her study of courtship and marriage during the eighteenth century, Nicole Eustace (2001) analyses a large number of letters that highlight the opposed attitudes of men and women during the pre-engagement stages. While gentlemen openly confessed their affection, ladies were much more restrained on this issue. However, as Eustace points out, these same young women did not hesitate to write extremely affectionate letters to their girlfriends.

Ladies' prudent attitude in hiding their feelings from their suitors can be attributed to two factors. On the one hand, at that time it was not appropriate for a young woman to openly show her preference for a gentleman with whom she was not engaged. And, on the other hand, during the courtship period, prior to the engagement, women enjoyed a position of power, which was unique during their lifetime. Although it is true that women acquired a position of greater relevance when they got married, it did not imply that they acquired total independence. The unmarried girl lived in her family home under the authority of her parents and, after marriage, this authority was transferred to her husband, who was the owner and lord of the home. However, during the courtship, young ladies enjoyed a privileged position, having the power to decide whether or not to accept their suitors, and as consequence, occasionally, some young women exercised that power, keeping their suitors in a state of uncertainty. In spite of how gratifying this situation could be for these young ladies, it was not prudent for them to overdo the exercise of this power, as it could have negative consequences.

When Eliza advised Betsy to "shew thyself a generous conquest," she added "(Do) not take pleasure in shewing thy power, neither stretch it to the limit, for thou knows these things are weakened when carried too far" (...). The period of courtship reversed the usual hierarchy of gender, making men subordinate to the whims of woman and allowing women the final say, perhaps the only time in their lives they would have it. (Eustace, 2001: 527)

It was a situation of power that could sometimes be exercised for long periods, as is the case of the young woman referred in the previous quote, and who took nine months to respond affirmatively to her suitor.

Once the young lady agreed to her suitor, her previous reluctance to express her affection could be attributed to the sense of decorum or fear of showing her feelings too soon. However, after the engagement, it was not convenient for the lady to keep the same attitude. In fact, any doubt about her affection towards her fiancé should be avoided. 


\subsection{The entailment}

In Pride and Prejudice, Jane Austen used a legal device to increase the drama in the story. As it is explained at the beginning of the novel, the estate of Longbourn is entailed, so that, after Mr. Bennet's death, it will pass to his cousin, Mr. Collins. Therefore, Mrs. Bennet and her daughters will lose their home and almost all their income.

This section will look at a brief explanation of the entailment and Austen's use of this legal device in Pride and Prejudice. As Appel (2012) explains, the aim of the entailment was to avoid the loss of family property:

English land law traditionally struggled with attempts to keep property within the family and restrict the ability of one member of the family to sell it. One such device was the entailment (also known as the fee tail), which allowed the patriarch of a family to pass property to one line of the family. If that line failed to produce descendants or if the descendants were not of the right sex (generally, male), the land would pass to another, more distant line of the family. (Appel, 2012: 611)

To prevent lands and possessions from being divided and devalued with the passing of generations, English legislation provided landowners with the necessary resources to ensure that their possessions would remain within their families. One of the existing provisions at the time, not only in England but in various countries, was the primogeniture (Cecil, 1895), which gave the first child (usually the first male child) most of the inheritance, while the rest of the descendants received only greater or lesser economic aid, depending on the wealth of the family.

Through primogeniture, it was guaranteed that the possessions passed from father to son from generation to generation. But what would happen if the heir had no offspring, or at least no male offspring? Or what if the heirs died before receiving the inheritance? The entailment allowed the testamentary part to choose his successive heirs, including the clauses that would be considered appropriate. Usually, the owner would appoint his son as his heir, and his son's and following generations' firstborn son. In the event that the succession was interrupted in the direct line, the goods would pass to the next heir according to the law, which could be a cousin, a nephew, a grandchild, etc.

The fee tail (...) allowed a donor to severely restrict the alienability of his heirs: to entail land was to grant limited interests to a number of persons in successionpersons who were often not yet born and would not be for several generations - so that no one possessor was absolute owner, nor could anyone alter the future as it was mapped out by the donor's will. (Macpherson, 2003: 6)

Therefore, the heirs of possessions subject to entailment could not dispose of them according to their will, bequeathing them to whom they deemed appropriate. The heir was not the owner of the inheritance, but only its usufructuary.

In his article on the entailment in Pride and Prejudice, Appel (2012) analyses England's legal situation at the time in which the story takes place, and points out the circumstances that have aroused controversy among scholars of the novel. Appel states that at the end of the eighteenth century, it was possible for the heir to bar the entailment with a simple legal procedure. Therefore, Mr. Bennet could have avoided the situation that was so distressing to his wife and daughters. For this reason, in some studies it is 
stated that Longbourn was not subject to an entailment but to a strict settlement, a legal device partly similar to the entailment, but more difficult to bar. It is not our objective to analyse this controversy, so we will assume Appel's conclusions, which affirms the validity of the explanations provided by Austen in her novel, in which she repeatedly refers to the entailment. As Apple says, it is not unusual for citizens to ignore some nuances of the laws that directly affect them, so the fact that Mr. Bennet, like many other English men, did not know the legal details of the entailment does not reduce the credibility or the realism of the novel.

The first chapters of Pride and Prejudice, besides explaining that Longbourn is subject to entailment, also state that Mr. Bennet had not seen the need to save in order to provide some future security for his family, since he trusted to have a son who would inherit his possessions. However, having had five daughters and not expecting more offspring, when he dies, Longbourn and his rents will be inherited by the closest male relative: Mr. Collins.

\section{ANALYSIS OF MR. COLLINS' PROPOSAL}

Now that the historical context has been established, we will address the central point of this article: to analyse chapter 19 of Pride and Prejudice, which relates the marriage proposal of Mr. Collins to Elizabeth Bennet and which, as it will be seen below, contains many of the social and cultural aspects explained in the previous sections.

Two of the main characteristics of Jane Austen's style are her characters' coherence and her skill in writing dialogues (Jordán, 2017). Austen created varied characters for her novels and she always included information in them which would allow readers to understand a character's personality, not by means of long psychological descriptions, but through narrator's comments and primarily through each character's words.

As it will be shown below, throughout the conversation, Mr. Collins is convinced that Elizabeth will accept his hand and, for this reason, misunderstands her words and gestures. According to Al-Haj (2014), Mr. Collins is portrayed by Austen as a fool and for this reason he is oblivious to other people's feelings and reactions. Laumber (1998: 214) affirms that for him personal feelings are irrelevant, only the ceremony counts. Thus, Elizabeth needs to raise the intensity of her refusals so that Mr. Collins will comprehend that he is being rejected. The reasons that justify Mr. Collins' confidence in the success of his proposal will also be explained later. Now we will begin our analysis, transcribing here the most relevant parts of the dialogue:

"Believe me, my dear Miss Elizabeth, that your modesty, so far from doing you any disservice, rather adds to your other perfections. You would have been less amiable in my eyes had there not been this little unwillingness; but allow me to assure you, that I have your respected mother's permission for this address." (Austen, 1853: 93)

Mr. Collins, after praising Elizabeth and confusing her refusal with modesty, assures her that he has the blessing of her mother for the task he intends to carry out. As explained in section 3, the first step in the protocol of a marriage proposal was to request the consent of the parents. If the proposal had their approval, they could allow the suitor 
to speak directly with the lady. As explained in the novel, Mr. Collins has the full approval of Mrs. Bennet, who actually forces Lizzy to listen to her suitor.

"Almost as soon as I entered the house, I singled you out as the companion of my future life. But before I am run away with by my feelings on this subject, perhaps it would be advisable for me to state my reasons for marrying - and, moreover, for coming into Hertfordshire with the design of selecting a wife, as I certainly did." (Austen, 1853: 93)

Austen's witty irony is present throughout the whole scene, pervading the text with humour. We detect this irony in Mr. Collins' words: "Almost as soon as I entered the house...". It is true that Mr. Collins chose Elizabeth as a possible wife "almost as soon as" he entered the house, since, previously, he had pinned his hopes on Jane, the eldest and most beautiful daughter, but when Mrs. Bennet informed him that she was about to receive a proposal from Mr. Bingley, he had no qualms about transferring his interest to her sister Elizabeth. Throughout the whole proposal it can be appreciated how Mr. Collins carries his formality and affected humility to the point of ridiculousness (Nash, 1999). Despite his excessive formality, he violates basic politeness maxims when proposing to Elizabeth, although unconsciously. There is no malice in him, only clumsiness and lack of social intelligence (Partanen, 2019: 9).

Mr. Collins makes his proposal following a pre-established script with a clear structure. First, he must explain the reasons that lead him to the marriage and, in particular, to choose someone from Hertfordshire. Once this is done, he will allow his feelings to take over. This structure reinforces the conception of marriage as a negotiation, in which an advantageous agreement is sought for all parties.

One of the tasks of the clergymen, as explained in point 2, was to set an example for their parishioners through their right conduct in the performance of their tasks and the fulfillment of their duties, and Mr. Collins has this in mind when he explains: "My reasons for marrying are, first, that I think it a right thing for every clergyman in easy circumstances (like myself) to set the example of matrimony in his parish" (Austen, 1853: 94). It was also said that the income of the clergy was sometimes scarce. Therefore, Mr. Collins' explanation is completely consistent with this situation. His obligation is to set an example to his parishioners and, as he finds himself in a good economic situation, he can face the task of getting married and forming a family.

When speaking of the marriage of the clerics, it was affirmed that the parish clergyman's wife could be of great help and provide spiritual understanding and support. So, Mr. Collins is right in being righteously convinced that marriage will contribute to his happiness as he states during his proposal: "secondly, that I am convinced that it will add very greatly to my happiness" (Austen, 1853: 94).

The third reason, (although as Mr. Collins says, it may be the main one) is to follow the advice of his patroness: "it is the particular advice and recommendation of the very noble lady whom I have the honour of calling patroness" (Austen, 1853: 94). Point 2 explained in detail the need for clerics to have the patronage of a relevant person, since their livelihood could depend on it. So it is not surprising that Mr. Collins is so willing to obey Lady Catherine de Bourgh's instructions, which he transmits to Elizabeth. 
(...) she said, "Mr. Collins, you must marry. A clergyman like you must marry. Choose properly, choose a gentlewoman for my sake; and for your own, let her be an active, useful sort of person, not brought up high, but able to make a small income go a good way." (Austen, 1853: 94)

Mr. Collins reproduces the energetic tone of his patroness, which details not only his obligation to marry, but also the characteristics of his future wife. As explained a few paragraphs above, being in a good economic situation, Mr. Collins is forced to set an example for his parishioners by getting married. Clergymen's wives were responsible for the economy of the rectory and helped their husbands in some tasks. That is why it is not striking that Lady Catherine indicates that he should choose an active, useful woman who does not have many aspirations and knows how to manage small incomes well.

Mr. Collins makes a slight digression in his speech to emphasise another of the advantages of his situation: "Allow me, by the way, to observe, my fair cousin, that I do not reckon the notice and kindness of Lady Catherine de Bourgh as among the least of the advantages in my power to offer" (Austen, 1853: 94). As already mentioned at the beginning of this section and in point 3 , the marriage proposal was conceived as a negotiation in which the man had to highlight the advantages of his economic and social situation. To count on the benevolence and protection of a Lady was certainly an advantage for the parish clergyman.

Following the pre-established script, after enumerating the reasons that led him to consider marriage, Mr. Collins goes on to explain why he has decided to look for a wife in Longbourn and not in his parish. Longbourn is subject to an entailment and, when Mr. Bennet dies, Mr. Collins will inherit both the house and the lands. So Mrs. Bennet and her daughters will be left homeless and with little income. Mr. Collins cannot avoid the entailment, so he is not guilty of the situation in which the Bennets will remain. He could remedy it by renouncing the inheritance, but that was not a usual practice. Even so, he might feel some remorse because of the uncertain future that awaited her distant relatives. So, in an attempt to alleviate the suffering of the family and to reassure his conscience, Mr. Collins shows his intention to marry one of the Bennet ladies, and in this way, they will not need to leave the house after Mr. Bennet's death, since Mr. Collin's will welcome them as long as necessary.

Certainly, Mr. Collins' proposal is a solution to the Bennets' great problem, and the fact that he has decided to offer them that possibility is something worthy of being praised, since he had no obligation to do so. Therefore, it is understandable that he thinks himself to deserve Elizabeth's gratitude. However, he does not realize that in his proposal he only shows selfish reasons for marrying and in addition humiliates Elizabeth by pointing out the vulnerability of her situation (Al-Haj, 2014: 47).

After explaining his reasons for marrying and choosing a wife in Longbourn, it is time for Mr. Collins to express his affection for Lizzy: "And now nothing remains for me but to assure you in the most animated language of the violence of my affection" (Austen, 1853: 95). In section 3, it was said that during the period of courtship and in the proposal, the rhetoric of love tried to conceal the economic and social interests existing in the relationship. In the case of Mr. Collins, this rule is not fulfilled since he decides to address social issues first and then resorts to loving rhetoric. 
As a matter of fact, "the violence of Mr. Collins' affection" for Elizabeth results into his promise to not reproach her for the lack of financial means:

"To fortune I am perfectly indifferent, and shall make no demand of that nature on your father, since I am well aware that it could not be complied with; and that one thousand pounds in the four per cents, which will not be yours till after your mother's decease, is all that you may ever be entitled to. On that head, therefore, I shall be uniformly silent; and you may assure yourself that no ungenerous reproach shall ever pass my lips when we are married." (Austen, 1853: 95)

Although within the context of the scene, and taking into account the characteristics of Mr. Collins, this statement may seem comical, grotesque, or even rude, certainly it is an attitude of great generosity, since Mr. Collins is willing to marry a young woman who can hardly contribute some money to the marriage.

Aware of being a good match because of his social position and economic stability, Mr. Collins assumes that his proposal has been accepted. But Elizabeth interrupts him and, after thanking him for his deference to her and the generosity of his feelings, rejects the offer clearly and firmly. According to Stout (1982: 323), Mr. Collins is not honest in his interest, since he does not care about Elizabeth but only about himself, and for this reason he thinks that Elizabeth is not honest either when she rejects him. Besides, as it has already been said, Mr. Collins is so convinced of the advantages that this marriage would bring to Elizabeth that, once again, he misinterprets her words and attributes them to a usual strategy of the ladies.

"I am not now to learn," replied Mr. Collins, with a formal wave of the hand, "that it is usual with young ladies to reject the addresses of the man whom they secretly mean to accept, when he first applies for their favour; and that sometimes the refusal is repeated a second, or even a third time." (Austen, 1853: 95)

Elizabeth denies that intentionality and questions this practice among the ladies "if such young ladies there are" - but Mr. Collins insists on understanding her attitude in that way. Thus, every refusal of Lizzy is interpreted by him as an invitation to persevere in his endeavour.

In section 2.2 it was commented that, according to the examples studied by Eustace, during the eighteenth century it was customary for men to openly express their feelings, while ladies tended to be less prone to these displays of affection. It was also explained that the courtship period was the only time when young women enjoyed a position of power with respect to their suitors and that, on occasion, this could cause a certain delay in the acceptance of the proposal. However, it does not seem that it was a usual practice to reject in an energetic way a suitor to whom one wanted to accept. Mr. Collins' confusion at this point would be easily explained because of his lack of experience regarding courtship and women's behaviour.

Elizabeth insists on the authenticity of her rejection and Mr. Collins answers her explaining the reasons why he is convinced that it is only a female strategy.

"My reasons for believing it are briefly these: It does not appear to me that my hand is unworthy of your acceptance, or that the establishment I can offer would be any other than highly desirable. My situation in life, my connections with the family of de Bourgh, and my relationship to your own, are circumstances highly in my favour." (Austen, 1853: 96) 
Mr. Collins is aware of what he brings to marriage: his situation in life, both economic and social, his connections with a member of the aristocracy, and the kinship with the Bennets, which implies the solution to Longbourn's entailment. Considering that marriage was, for many women of that time, the only possibility of securing their future and maintaining a certain social status, Mr. Collins' offer is not insignificant, since it guarantees a home with moderate but sufficient income and a good social position. In fact, by reading further in Pride and Prejudice, it can be seen how Charlotte Lucas appreciates these circumstances and benefits from them.

Mr. Collins' reasons for being sure of the convenience of his marriage to Elizabeth include not only his good economic and social position, but also the disadvantageous situation of his cousin:

“(...) and you should take it into further consideration, that in spite of your manifold attractions, it is by no means certain that another offer of marriage may ever be made you. Your portion is unhappily so small that it will in all likelihood undo the effects of your loveliness and amiable qualifications." (Austen, 1853: 95)

In a negotiation it is important to know the strengths and weaknesses of both parties. Mr. Collins is not only aware of what he can offer, but also of what Elizabeth can expect. Elizabeth is an attractive and intelligent young woman, but neither her economic situation nor her connections make her an object of interest for gentlemen of good standing. This fact is stated in a conversation between Mr. Darcy and the Bingley family:

"I have an excessive regard for Jane Bennet; she is really a very sweet girl, and I wish with all my heart she were well settled. But with such a father and mother, and such low connections, I am afraid there is no chance of it."

"I think I have heard you say that their uncle is an attorney in Meryton."

"Yes; and they have another, who lives somewhere near Cheapside."

"That is capital," added her sister, and they both laughed heartily.

"If they had uncles enough to fill all Cheapside," cried Bingley, "it would not make them one jot less agreeable."

"But it must very materially lessen their chance of marrying men of any consideration in the world," replied Darcy. (Austen, 1853: 30)

Mr. Collins' words, once again, though lacking in tact and opportunity, are a reflection of the reality of his time. Marriage during the eighteenth and early nineteenth centuries continued to have a wide social impact and, although feelings were something to be taken into account, they were not the only determining factor.

Mr. Collins' reasoning fails to convince Elizabeth, who insists on her rejection of the marriage proposal, using an increasingly firm tone. Therefore, Mr. Collins, determined to succeed, resorts to the final instance to achieve his purpose: her parents' authority: "I am persuaded that when sanctioned by the express authority of both your excellent parents, my proposals will not fail of being acceptable" (Austen, 1853: 97).

As it has been seen, Mr. Collins' proposal lacks the romantic tone, which would be expected to be found in such a situation. However, this fact is completely coherent with the former behaviour of the character and his comic nature. According to Laumber (1998): 
Mr. Collins is the most amusing fool in Pride and Prejudice, despite of his humourless and pedantic nature. His marriage proposal to Elizabeth is so far away from the passion and genuine care usually present in these situations, that it provokes laughter. (34)

As explained in point 3, it was not customary for parents to arrange a marriage for their children. Although young people were supposed to enjoy some freedom to choose, it was not uncommon that family pressure resulted to be decisive in the acceptance or rejection of a proposal. This circumstance is reflected in other Austen's novels. In Persuasion (2011a), it is explained that Anne Elliot rejected Captain Wentworth because of the pressure exerted by her family and friends. Mansfield Park (1988) narrates the siege to which Fanny Price is subjected by her uncle to accept the hand of Henry Crawford. And in Sense and Sensibility (1833), Mrs. Ferrars pressures her son Edward to prevent him from marrying Lucy Steele.

In the case we are analysing, despite Elizabeth's strong personality, we can imagine the awkward situation that would have arisen if her father had sided with Mr. Collins and insisted his daughter to accept the proposal. Although the final decision is for Elizabeth, the weight of external factors could be decisive. However, as the readers of this novel well know, Mr. Bennet shares his daughter's opinion and not only does he not ask her to accept Mr. Collins but, with his usual sarcasm, states that he will not talk to her again if she does.

\section{CONCLUSION}

Jane Austen's novels are a faithful reflection of the society of her time. However, she does not describe social customs, nor does she relate historical facts. Rather, she shows them as a part of her characters' lives. Austen is a realistic writer, who bases her novels on the study of her characters, and, for this reason, her way of depicting the sociocultural context in which she lived is through her characters' words and actions.

In the present article, a brief historical and social context about the life of the clergymen, courtship customs, and marriage proposals has been described, as well as basic information about the legal device of the entailment. As it has been brought to light in point 5, Austen faithfully reflects the situation of her time and makes her characters behave coherently with their sociohistorical context. At the same time, Austen highlights the negative consequences of a variety of customs and rules of her period by means of her use of irony and the way she designs certain characters.

In the scene that we analysed in the previous section, Austen evidences the precarious situation of many women, who were forced to accept a marriage proposal as the only means of securing their future. Marriages, like the one Austen describes in this scene, are reduced to a commercial agreement between two people. The man offers a social and economic situation, and the woman, lacking other options and aware of her vulnerability, her companionship. The affection between the contracting parties does not have any relevance, since the objective of this agreement is only material.

Austen carries out social criticism without the need to issue any judgment. The use of irony, the design of characters and situations, and sociohistorical fidelity are the 
strategies she uses to achieve this end. When choosing a character like Mr. Collins, endowed with caricatural features, Austen confers a comical tone to a scene in which a situation of social injustice is revealed. Through the character of Mr. Collins, Austen reflects the reality of her time faithfully and crudely. Mr. Collins' proposal contains many realistic elements, but the author narrates it in a comical and ironic way. Thus, Austen was able to perform social criticism without the risk of offending her contemporary readers. Austen does not denounce injustices with a rebellious or subversive style. She simply reveals reality, underlining the aspects she considers most relevant, and softening or hiding this criticism through an intelligent and delicate irony.

\section{REFERENCES}

Al-Haj, A. A. M. (2014). The Portrayal of Male Fools in Jane Austen Pride and Prejudice. English language and Literature Studies, 4 (2), 44-50.

Ailwood, S. (2021). Jane Austen, Feminist Legal Philosopher. In M. Kramp (Ed.), Jane Austen and Critical Theory, 232-247. London: Routledge.

Appel, P. A. (2012). A Funhouse Mirror of Law: The Entailment in Jane Austen's Pride and Prejudice. Georgia Journal of International and Comparative Law, 41 (3), 609-636.

Austen, J. (2011). Jane Austen's Letters. D. Le Faye (Ed.), Oxford: Oxford University Press.

Austen, J. (1853). Pride and Prejudice. London: Richard Bentley.

Austen, J. (1833). Sense and Sensibility. London: Richard Bentley.

Austen, J. (1988). Mansfield Park. R. W. Chapman (Ed.), Oxford: Oxford University Press.

Austen, J. (2011). Persuasion: An Annotated Edition. R. Morrison (Ed.), Cambridge MA: Harvard University Press.

Barrie-Curien, V. (1992). Clergé et pastorale en Angleterre au XVIIIè siècle: le diocèse de Londres. [Clergy and pastoral in England during the eighteenth century: the diocese of London]. Paris: Editions du Centre national de la recherche scientifique.

Brownstein, R. M. (1988). Jane Austen: irony and authority. Women's Studies: An Interdisciplinary Journal, 15 (1-3), 57-70.

Cecil, E. (1895). Primogeniture: A Short History of Its Development in Various Countries and Its Practical Effects. London: J. Murray.

Clark, G. K. (2018). Churchmen and the Condition of England 1832-1885: A Study in the Development of Social Ideas and Practice from the Old Regime to the Modern State. London: Taylor \& Francis Limited.

Eustace, N. (2001) "The cornerstone of a copious work": love and power in eighteenthcentury courtship. Journal of Social History, 34 (3), 517-546.

Hempton, D. (1996). Religion and Political Culture in Britain and Ireland: From the Glorious Revolution to the Decline of Empire. Cambridge: Cambridge University Press. 
Jacob, W. M. (2007). The Clerical Profession in the Long Eighteenth Century, 16801840. Oxford: Oxford University Press.

Jordán, M. A. (2017). Análisis del estilo literario de Jane Austen [Analysis of the literary style of Jane Austen]. Valencia: Universitat de València, http://roderic.uv.es/handle/10550/59048.

Kloester, J. (2010). Georgette Heyer's Regency World. Chicago: Sourcebooks, Inc.

Laumber, S. (1998). Jane Austen: Pride and Prejudice. London: Macmillan.

Macpherson, S. (2003). Rent to Own; or, What's Entailed in Pride and Prejudice. Representations, 82 (1), 1-23.

Mudrick, M. (2018). Jane Austen: Irony as defense and discovery. Great Barrington MA: Berkshire Publishing Group.

Nash, G. (1999). Jane Austen and Pride \& Prejudice. London: Longman.

Partanen, H. K. (2019). "There is something very pompous in his style": An analysis of Mr Collins' social missteps in Pride and Prejudice. Bachelor Thesis. University of Jyväskylä

Smith, D. S. (1973). Parental power and marriage patterns: An analysis of historical trends in Hingham, Massachusetts. Journal of Marriage and the Family, 35 (3), 419-428.

Stout, J. P. (1982). Jane Austen's proposal scenes and the limitations of language. Studies in the Novel, 14 (4), 316-326.

Puspita, M. \& Pratama, P. (2019). The value of feminism in Pride and Prejudice by Jane Austen and the implications for language teaching. English Empower: Journal of Linguistics and Literature, 4 (2), 65-74. 